\title{
THE SOCIO-ECONOMIC IMPACTS OF NIZAM ZACHMAN OCEANIQUE FISHING PORT ACTIVITIES ON THE COMMUNITY AND ITS SURROUNDING ENVIRONMENT
}

\author{
Ernani Lubis ${ }^{12 *}$, Retno Muninggar ${ }^{2 a}$, Budhi Hascaryo Iskandar ${ }^{3 \mathrm{a}}$ and John Haluan ${ }^{4 \mathrm{a}}$
}

IPB University, Komplek IPB Sindangbarang 2, Jalan Icarus Blok O. No. 10, Bogor, 16680, INDONESIA. Email: ernani_ipb@yahoo.com ${ }^{1}$; muninggar@apps.ipb.ac.id ${ }^{2}$; budhihascaryo@apps.ipb.ac.id ${ }^{3}$; jhaluan@yahoo.com ${ }^{4}$

Corresponding author: ernani_ipb@yahoo.com

Received: 15 $5^{\text {th }}$ Jul $2019 \quad$ Accepted: $12^{\text {th }}$ Nov 2019

Published: $30^{\text {th }}$ Jun 2020

DOI: https://doi.org/10.22452/mjs.vol39no2.2

\begin{abstract}
The existence of the Nizam Zachman Oceanique Fishing Port (NZOFP)-Jakarta had a socio-economic impact on the people in areas around the fishing port considered as buffer zones. The negative impact was observed on the environment in the forms of waste disposal (into waters and land), decreasing water quality, the emergence of odors and the unavailability of clean water. The research used a case study approach with case units in the forms of stakeholders and the community perceptions around NZOFP. The analysis of the socio-economic aspects of the existing condition at NZOFP refers to the socio-economic data in the area around NZOFP, namely Penjaringan Muara Baru District, North Jakarta. The analyzed aspects were: (1) the number of workers involved in the NZOFP area, (2) Community income (respondent), and (3) Community perception of the existence of the NZOFP. The ratio of the number of workers in NZOFP and the total workforce in the Penjaringan area of North Jakarta was $82 \%$. This number suggests that labor absorption through the sample data has met the standard of at least $20 \%$. The results of the income analysis showed that $50 \%$ of the respondents had income above Rp. 3,100,000 (above the Minimum Wage of Workers in DKI Jakarta). The analysis of respondents 'perceptions of the exis NZOFP was in Medium (25\%), Good (54\%), and Very Good (19\%). The analysis of respondents' behavior in disposing of garbage showed that knowledge and habit variables were factors influencing behavior, while the educational level did not affect.
\end{abstract}

Keywords: fishing port, impact, socio-economic

\section{INTRODUCTION}

The existence of the NZOFP had a socio-economic impact on the people in areas around the fishing port considered as buffer zones. The positive effect of the socio-economic aspects of the port growth on the community was the growth of employment opportunities in both fishing port and non-fishing port sectors, as well as the growth of the community income levels (Siahaan, 2012). On the other hand, the negative impact was observed on the environment in the forms of waste disposal (into waters and land), decreasing water quality, the emergence of odors, and the unavailability of clean water. Those problems are often found in Indonesian fishing ports (Zulfa et al. 2016; Risnandar 2013; Hakim 2013). Efforts to reduce the environmental impacts have been regulated in Indonesian Law No. 32 of 2009 through various environmental management and monitoring programs. These efforts involved port managers, environmental supervisors, and the active role of port users (stakeholders) and communities in the fishing port area. 
The problem faced by the NZOFP is the lack of awareness of both the port users and the surrounding community in protecting the environment. The NZOFP efforts to safeguard the environment, through cleaning programs and the implementation of K3 standards, have not been carried out optimally due to the lack of awareness of fishers in maintaining the environment around the port (for example). As a result of this lack of awareness, trash remains scattered on the edge of the pier and also in the waters. The problem of the low awareness of the stakeholders and the community will be quickly taken care of if the factors influencing their behaviors in protecting the environment are determined. Those factors could be determined by assessing respondents' perceptions of the environment.

Perception can be interpreted in the context of cognitive processes experienced by a person in understanding information about the surrounding environment through the five senses (Widyaningrum, 2013). A person's perception can be strengthened through knowledge and experience. It also affects human behavior in managing the environment. Some factors influencing people's behavior towards the environment include main factors (education, income, knowledge, attitude), supporting factors (availability of facilities), driving factors (health services) (Notoatmodjo, 2003). The community perceptions of the environment depend on the direct or indirect impacts on activities and facilities supporting people's lives in the forms of socio-economic, cultural, and educational levels (Liana 1994). A positive perception of the community towards an activity is reflected in positive responses because the perceived benefits and the community will support the activity. The negative perception of the community towards an activity is reflected in the negative response to the activity because of the negative impact felt by the community (Hasibuan 2013).

There is no information about stakeholder and community perceptions of the environment at NZOFP, while this information is critical in policy planning and implementation of environmental management programs. The previous chapter explained that there were still obstacles such as low public awareness on garbage disposal behavior. Consequently, the present research explores the factors related to the behaviors of stakeholders and the community in managing the environment. The objectives of this study are as follows: (1) measure the level of employment and income of the community, (2) measure stakeholder perceptions on the existence of NZOFP, (3) identify factors related to stakeholder behavior in protecting the environment (namely garbage disposal behavior).

\section{METHODOLOGY}

The present study was conducted at the Nizam Zachman Oceanique Fishing Port (Jakarta) from September to December 2016. The research used a case study approach with case units in the forms of stakeholders and the community perceptions around NZOFP.

The analysis of the socio-economic aspects of the existing condition at NZOFP refers to the socio-economic data in the area around NZOFP, namely Penjaringan Muara Baru District, North Jakarta. The analyzed aspects were: (1) the number of workers involved in the NZOFP area, (2) Community income (respondent), and (3) Community perception of the existence of the NZOFP.

Primary data collection was carried out through interviews and research questionnaires. The questionnaires were designed to collect port user perception 
data on the environmental impacts caused by port operational activities and respondents' behavior on environmental cleanliness (garbage disposal behavior). Meanwhile, secondary data on the aspects of labor absorption were obtained through population data in Penjaringan, North Jakarta. Data for the analysis of the aspects of community income were obtained through questionnaires.

The sample of respondents was determined using a non-proportional sampling quota. This method is used to ensure that various characteristics of the sample represent various subgroups in the population to a certain extent desired by the researcher (Kuncoro, 2013).

The non-proportional sampling quotas were chosen because the design was considered the best to meet the research objectives. The number of samples taken was 44 respondents reflecting the stakeholders of NZOFP, namely people who work and activities in the port. The data of the group of respondents used as the research sample are presented in Table 1.

Table 1. Respondent groups

\begin{tabular}{llc}
\hline No & Type of work & Number of Samples \\
\hline 1 & NZOFP Officer & 10 \\
2 & Company Employees in the NZOFP area & 9 \\
3 & Informal Sector Actors around NZOFP & 12 \\
\hline No & Type of work & Number of Samples \\
\hline 4 & Actors of Fish Landing and Marketing activities at & 13 \\
\hline & NZOFP & 44 \\
\hline \multirow{2}{*}{ No } & Sotal & Number of Samples \\
\hline 1 & Fishery & 26 \\
2 & Non-Fisheries & 18 \\
\hline & Total & 44 \\
\hline
\end{tabular}

Source: Primary data (2016)

\subsection{Absorption of labor and income of respondents}

Labor refers to a person able to work to produce goods and or services both to fulfill his/her own needs and for the community (Law No. 13 of 2003). The population of a country is divided into two groups, i.e., labor and not labor. The population is classified as labor if it has entered the working-age (productive age).
The working-age limit in Indonesia is 15 64 years (BPS North Jakarta 2016).

One of the standard criteria for eco-port is the involvement of buffer zone communities in port activities in both formal and informal sectors, which can be up to 20\% (Siahaan 2012). Analysis of employment absorption used the percentage of labor absorption formula adopted by Satari et al. (2015): 


$$
P T K=\frac{J T K}{J P K} \times 100 \%
$$

Description:

PTK = employment at NZOFP

JTK $=$ Number of workers at NZOFP

JPK $=$ The working-age population in Penjaringan Village

Data analysis for community income (respondents) used a qualitative descriptive analysis approach. The analysis of respondents 'income level was done by comparing respondents' income with secondary data related to the Minimum Wage in DKI Jakarta Province in 2016.

\subsection{Respondents' perceptions of NZOFP and the environment}

Stakeholder perceptions in NZOFP represented by respondents were assessed to measure their perception of the environmental impacts caused by port operations and respondents' behavior on environmental cleanliness, i.e., the garbage disposal behavior. The analysis of the respondents' perceptions of port impacts was carried out using a qualitative descriptive approach, while that of respondents' behavior in disposing of waste was done through the determination of the factors influencing behaviors.

The perception analysis used respondents' assessment criteria for the existence of NZOFP, as well as the impact felt. The assessment criteria used in the respondents' perception questionnaire was the Likert scale. Respondents gave a rating between 1 (very bad) and 5 (very good). According to Manalu et al. (2013), the Likert scale is also called the Summated Ratings Method. Using the Summated Ratings Method will lead to the determination of a score on the Likert scale measurement, giving the highest and lowest assessments for each answer to the question posed to the respondent.

The determination of the factors influencing respondents' behavior in protecting the environment, especially garbage disposal behavior, was carried out with a bivariate analysis approach. The Bivariate analysis is an analysis conducted on two variables that are allegedly related or correlated (Notoatmodjo, 2003). The independent variable was garbage disposal behavior with dependent variables, namely Education, Knowledge, and Habit. ChiSquare testing was then used on statistical software tools. Data testing formula used the Chi-Square test (Sugiyono 2005):

Description:

$$
X^{2}=\sum\left(\frac{f o-f h}{f h}\right)
$$

\footnotetext{
$\square^{2}=$ Chi-Square

$\square \square \quad=$ Frequency that is observed

$\square h \quad=$ The expected the frequency
} 
Decision making based on probability. If the probability is $<0.05$, then $\mathrm{H} 0$ is rejected. This assumption shows that both variables correlated. If $\mathrm{H} 0$ is accepted, it means that the two variables are uncorrelated. The degree of closeness of the relationship between independent and dependent variables is determined through the criteria of the correlation coefficient, as explained in Table 2.

Table 2. Correlation coefficient criteria

\begin{tabular}{cc}
\hline Coefficient Interval & Relationship Level \\
\hline $0.000-0.199$ & very low \\
$0.200-0.399$ & low \\
$0.400-0.599$ & medium \\
$0.600-0.799$ & strong \\
$0.800-1.000$ & very strong \\
\hline
\end{tabular}

Source: Sugiyono (2002)

\section{RESULTS AND DISCUSSION}

\subsection{Absorption of labor and income respondents}

The characteristics of respondents revealed that out of 44 respondents interviewed, there were characteristic distributions regarding age, sex, education, employment, income, information about environmentallysounding ports, and information sources. It was observed in Table 3 that respondents who already know or have heard about environmental-oriented ports were $43 \%$, less than those who have never known or heard about environmentaloriented ports $(57 \%)$. This aspect is the duty of the port manager so the community can know that information about the eco fishing port. Socialization activities related to environmental information on ports can be carried out through counseling, media promotion, and collaboration with relevant agencies such as fisher groups, schools, RT/RW administrators, and local government.

Table 3. Distribution frequency of respondents based on characteristics

\begin{tabular}{cccc}
\hline No. & Characteristics & $\mathrm{N}$ & $\%$ \\
\hline 1 & Age & & \\
& $18-27$ Years & 22 & 50 \\
$26-37$ Years & 6 & 14 \\
$38-47$ Years & 11 & 25 \\
& $48-57$ Years & 5 & 11 \\
\hline & Total & 44 & 100 \\
& Gender & & \\
& Male & 40 & 90 \\
& Female & 4 & 100 \\
\hline
\end{tabular}


3

Education

Elementary

$7 \quad 16$

JHS

12

27

SHS

17

39

Vocational/Bachelor

Total

8

18

\begin{tabular}{ccc} 
Vocational/Bachelor & 8 & 18 \\
\hline Total & 44 & 100 \\
\hline
\end{tabular}

4

Jobs

\begin{tabular}{ccc} 
Fishery sector & 26 & 60 \\
Non-fishery sector & 18 & 40 \\
\hline Total & 44 & 100
\end{tabular}

5

Income (Rp/month)

500.000-1.500.000

$3 \quad 7$

1.500.000-3.100.000

1943

Above 3.100.000

22

50

Total

44

100

6

Port information

Environmentally friendly

Know 19 43

Do not know 25 57

\begin{tabular}{ccc} 
Do not know & 25 & 57 \\
\hline Total & 44 & 100 \\
\hline
\end{tabular}

7

Sources of information

$\begin{array}{ccc}\text { Port } & 17 & 39 \\ \text { Others } & 2 & 4 \\ \text { the information. } & 25 & 57 \\ \text { Total } & 44 & 100\end{array}$

Source : data primer yang telah diolah (2016)

The analysis of employment used data on employment in NZOFP in 2016, presented in Table 4. Based on Table 4, the number of workers in NZOFP was 53.205 people. Penjaringan Village workforce was 64.806 people (BPS Kota Jakarta Utara, 2016). 
Table 4. Workforce at NZOFP in 2016

\begin{tabular}{ccc}
\hline No & Type of work & Number of people \\
\hline 1 & Fishers & 30,033 \\
2 & Non-fishers: & 23.172 \\
& a. Government agencies & 639 \\
& b. Formal business sector & 8,351 \\
& c. Informal business sector & 14.182 \\
\hline & Total & 53.205
\end{tabular}

Source: NZOFP (2017)

$$
\begin{aligned}
\text { PTK } & =\frac{\mathrm{JTK}}{\mathrm{JPK}} \times 100 \% \\
& =\frac{53.205}{64.806} \times 100 \% \\
& =82.1 \%
\end{aligned}
$$

The ratio of the number of workers in NZOFP to the total workforce in the Penjaringan village of North Jakarta was $82 \%$, showing that the absorption of labor based on sample data met the minimum standard of $20 \%$. This condition can occur because residents working at NZOFP not only come from Penjaringan Village but also various regions (Jakarta and outside Jakarta).

The analysis of community income is carried out by referring to the provincial minimum wage standard. The minimum standard of income for the people of DKI Jakarta was determined based on the Jakarta Province Minimum Wage in 2016, according to the Regulation of the Governor of DKI Jakarta Province Number 230 of 2015 . In the mentioned regulation, the UMP of 2016 was Rp. $3,100,000$. The results of the analysis showed that there were $50 \%$ of respondents having incomes above $\mathrm{Rp}$. 3,100,000 (above the UMP). Respondents with income ranging between IDR $1,500,000-3,100,000$ represented $43 \%$, while those with income from IDR 500,000 to $1,500,000$ were $7 \%$. This condition showed that the absorption of the good workforce had increased the income of respondents working in NZOFP.

\subsection{Respondents' perceptions of NZOFP's existence}

The variables used in measuring respondents' perceptions consisted of 11 (eleven) variables on the positive and negative impact of the existence of NZOFP. The mentioned variables were tested for their validity and reliability with the help of statistical software. The validity is a measure showing that the measured variables are variables that researchers want to study (Santoso 2015). The reliability shows how far the measurement results with the tool can be trusted. The measurement results must be reliable in the sense that they must have a level of consistency and stability (Santoso, 2015). 
Table 5. Results of the validity and reliability of variables

\begin{tabular}{clcccc}
\hline Code & \multicolumn{1}{c}{ Variables } & r count & $\begin{array}{c}\text { r table } \\
(5 \%)\end{array}$ & $\begin{array}{c}\text { r table } \\
(1 \%)\end{array}$ & Validity \\
\hline V1 & The selling price of the & 0.298 & $>0.297$ & $<0.384$ & Valid \\
V2 & Business opportunity & -0.008 & $<0.297$ & $<0.384$ & Invalid \\
V3 & Catch quality & 0.762 & $>0.297$ & $>0.384$ & Valid \\
V4 & Open employment & 0.435 & $>0.297$ & $>0.384$ & Valid \\
V5 & Water quality at the port & 0.541 & $>0.297$ & $>0.384$ & Valid \\
V6 & Water quality at the port & 0.681 & $>0.297$ & $>0.384$ & Valid \\
V7 & Odor caused & -0.780 & $<0.297$ & $<0.384$ & Invalid \\
V8 & Sanitation in the port area & 0.813 & $>0.297$ & $>0.384$ & Valid \\
V9 & Security and order & 0.794 & $>0.297$ & $>0.384$ & Valid \\
V10 & Waste treatment facilities & 0.741 & $>0.297$ & $>0.384$ & Valid \\
V11 & Cleanliness port basin & 0.647 & $>0.297$ & $>0.384$ & Valid \\
\hline
\end{tabular}

Cronbach'Alpha $=0.724 *$

$*$ The value of Cronbach alpha $=0.724>0.600$; this shows the instrument used reliable. Source: Results of analysis (2016)

Table 5 shows that there are 2 (two) variables that do not meet the criteria for validity, namely Variable 2 (Business Opportunity) and Variable 7 (Odor generated). In general, the variables are reliable because they have a value of
Cronbach'Alpha $>0.600$. Variables having passed the validity and reliability test are then analyzed based on the results of the Likert scale criteria chosen by the respondents.

Table 6. Stakeholder Perceptions of the existence of NZOFP

\begin{tabular}{lccrrr}
\hline \multirow{2}{*}{ Variables } & \multicolumn{5}{c}{ Percentage of Respondents' Perceptions (\%) } \\
\cline { 2 - 6 } & Very Bad & Bad & Medium & Good & Very good \\
\hline The selling price of the catch & 0.00 & 0.00 & 0.34 & 0.61 & 0.05 \\
Catch quality & 0.00 & 0.00 & 0.09 & 0.66 & 0.25 \\
Open & 0.00 & 0.00 & 0.18 & 0.27 & 0.55 \\
opportunities & & & & & \\
Water quality at the port & 0.00 & 0.00 & 0.07 & 0.80 & 0.14 \\
Use of alternative energy & 0.00 & 0.00 & 0.20 & 0.57 & 0.16 \\
Sanitation in the port area & 0.00 & 0.00 & 0.43 & 0.41 & 0.11 \\
Security and order & 0.00 & 0.00 & 0.39 & 0.41 & 0.16 \\
Waste treatment facilities & 0.00 & 0.00 & 0.27 & 0.59 & 0.14 \\
Cleanliness port basin & 0.00 & 0.00 & 0.32 & 0.50 & 0.16 \\
\hline Average & 0.00 & 0.00 & 0.25 & 0.54 & 0.19 \\
\hline
\end{tabular}

Table 6 shows that $54 \%$ of respondents had positive perceptions for 9 (nine) variables on the impact of the existence of NZOFP. For the variable of employment opening, most respondents
$(55 \%)$ stated that it was "very good." In general, respondents' perceptions of the existence of NZOFP were moderate (25\%); Good (54\%), and Very Good (19\%). No respondents were observed in 
the Bad and Very Bad ratings. This result happened because respondents had felt the direct benefit of the existence of NZOFP, such as the selling price of good catches, good fish quality, and the presence of new jobs.

\subsection{Respondent's behavior in disposing of garbage}

Hygiene program, run by NZOFP, is still constrained by low awareness of port users and the people around NZOFP, indicated by the visibility of garbage in the port basin, on the outskirts of the port road and on the way out to the resident areas. Waste management efforts through sorting, collecting, and processing into new products are strongly supported by the active role of port users and the community. If they are still ignorant of the rules and have not prioritized the environment, then various environmental management policies and strategies will be difficult to implement.

The results of the bivariate analysis showed the relationship between Waste Disposal Behavior and the other three variables, namely Education, Knowledge, and Habit. The results of cross-tabulation between education and behavior of respondents in disposing of waste are presented in Table 7.

Table 7. Cross-tabulation between education level and disposing of behavior garbage

\begin{tabular}{lcccccc}
\hline & \multicolumn{5}{c}{ Garbage Disposal Behavior } \\
\cline { 2 - 7 } Education & \multicolumn{2}{c}{ In any place } & In the trash & \multicolumn{2}{c}{ Total } \\
\cline { 2 - 7 } & F & $\%$ & F & $\%$ & F & $\%$ \\
\hline Low (Elementry school) & 16 & 57.1 & 3 & 18.8 & 19 & 43.2 \\
$\begin{array}{l}\text { High school } \\
\text { (High school-university) }\end{array}$ & 12 & 42.9 & 13 & 81.3 & 25 & 56.8 \\
\hline Total & 28 & 100.0 & 16 & 100.0 & 44 & 100.0 \\
\hline
\end{tabular}

Source: processed primary data (2016)

$\mathrm{F}=$ Frequency

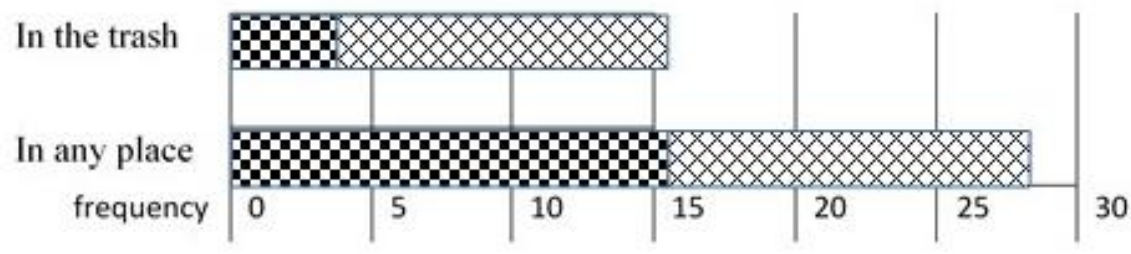

\begin{tabular}{|ll|c|c|}
\hline & & In any place & In the trash \\
\hline $\mathbf{X}$ & Low & 16 & 3 \\
\hline$\times$ & High & 12 & 13 \\
\hline
\end{tabular}

Figure 1. Graph of the Relationship between Education Level and Waste Disposal Behavior 
Table 7 showed that 16 people (57.1\%) disposing of garbage in any place were those with low education (elementary to junior high school level). Also, 12 people disposed of garbage in any place were respondents with a high educational background from school to university (42.9\%). On the other hand, the respondents throwing garbage in its place came from more highly educated $(56.8 \%)$ and less educated (43.2\%) respondents.

Based on the results of the testing using statistical software, the Chi-Square value was 6.117 with the value $-\alpha=0.013$ (shown in the Symp - Sig (2-sided) column. The test results showed that there was no relationship between the level of education and waste disposal behavior at a $1 \%$ significance level (- $\square>\alpha=1 \%)$. The results of this research applied only to samples in NZOFP related to the characteristics of the sample and limitations considered in this study. The results can be different in the place and object of research outside the NZOFP area.

The respondents used as the samples of the study were respondents with various educational backgrounds, from elementary to university levels. The results showed that there was no correlation between education and the behavior of disposing of garbage, whether arbitrary or in place. This result means that respondents in NZOFP having a high school education or higher education had the behavior of disposing of garbage that was almost the same as respondents who had elementary to junior high school education. On the other hand, educated people should be able to understand the importance of environmental health and hygiene.

\subsection{The relationship between knowledge and behavior of waste disposal}

Table 8. Cross-tabulation between education level and disposing of garbage behavior

The behavior of waste disposal

\begin{tabular}{lcccccc}
\cline { 2 - 6 } Knowledge & \multicolumn{2}{c}{ In any place } & \multicolumn{2}{c}{ In the trash } & \multicolumn{2}{c}{ Total } \\
\cline { 2 - 7 } & F & $\%$ & F & $\%$ & F & $\%$ \\
\hline Less & 17 & 60.7 & 2 & 12.5 & 19 & 43.2 \\
Good enough & 11 & 39.3 & 14 & 87.5 & 25 & 56.8 \\
\hline Total & 28 & 100.0 & 16 & 100.0 & 44 & 100.0
\end{tabular}

Source: processed primary data (2016)

$\mathrm{F}=$ Frequency 


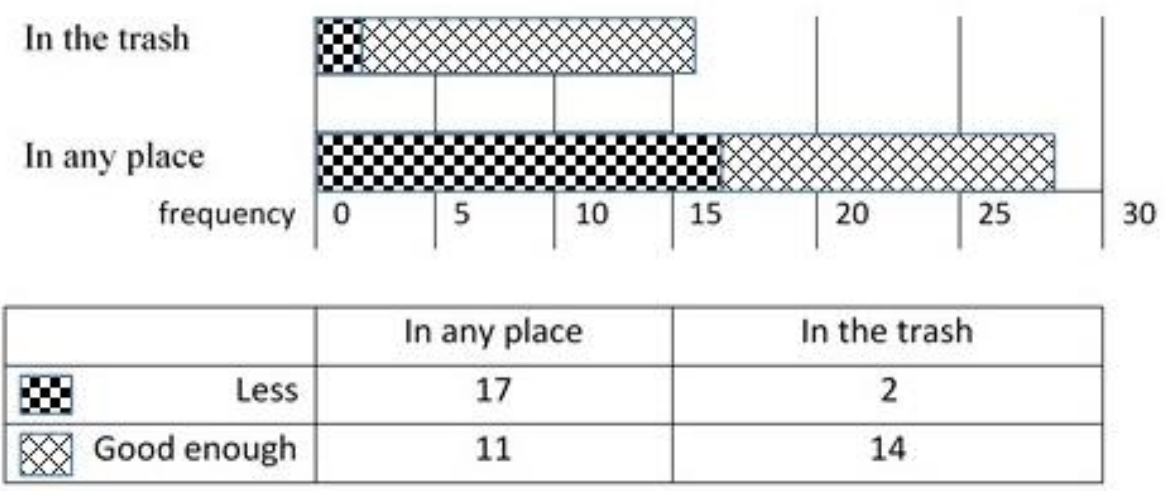

Figure 2. Graph of the Relationship between Knowledge and Garbage Disposal Behavior

Table 8 showed that 18 people $(60.7 \%)$ throwing garbage in any place were respondents having less knowledge (about the concept of environmental hygiene), while 11 people having the behavior of disposing of garbage in any place were respondents having sufficient to good knowledge ( $39.3 \%)$. The respondents throwing garbage in its place were those coming from educated backgrounds with enough knowledge $(87.5 \%)$, those with less knowledge amounted to $12.5 \%$. Respondents with enough knowledge throwing garbage in any place represented $39.3 \%$. Thus, the role of the NZOFP is to sensitize through socialization and counseling.

The test results using statistical software showed that the Chi-Square value was 9,647 , with the value $-a=0.002$ (which shown in the Symp - Sig (2sided) column. The test results also revealed that there was a relationship between Knowledge with Waste Disposal Behavior on a $1 \%$ significance level (- $a$ $<\alpha=1 \%)$. Pearson correlation showed number 0.468 , meaning that the variables of Knowledge and Behavior of Waste Disposal had a moderate relationship.

\subsection{Relationship between Knowledge and Disposal of Garbage}

Table 9. Cross-tabulation of garbage disposal behavior

\begin{tabular}{lcccccc}
\hline \multirow{2}{*}{ Habit } & \multicolumn{5}{c}{ Garbage Disposal Behavior } \\
\cline { 2 - 7 } & \multicolumn{2}{c}{ In any place } & In the trash & \multicolumn{2}{c}{ Total } \\
\cline { 2 - 7 } & F & $\%$ & F & $\%$ & F & $\%$ \\
\hline Not accustomed & 22 & 78.6 & 2 & 12.5 & 24 & 54.5 \\
Accustomed & 6 & 21.4 & 14 & 87.5 & 20 & 45.5 \\
\hline Total & 28 & 100.0 & 16 & 100.0 & 44 & 100.0 \\
\hline
\end{tabular}

Source: processed primary data (2016)

$\mathrm{F}=$ Frequency 


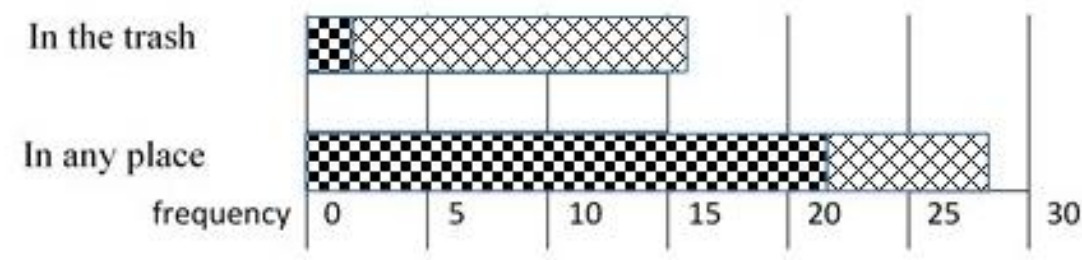

\begin{tabular}{|l|c|c|}
\hline & In any place & In the trash \\
\hline $\mathbf{X}$ Not accustomed to & 22 & 2 \\
\hline Accustomed & 6 & 14 \\
\hline
\end{tabular}

Figure 3. Graph of the relationship between habits and Garbage Disposal behavior

Table 9 showed that 22 people (78.6\%) disposing of garbage in any place were respondents without the habits of maintaining cleanliness. Also, 2 people with the habit of disposing of garbage in any place were respondents accustomed to maintaining cleanliness $(12.5 \%)$. On the other hand, respondents disposing of garbage in its place came from respondents with the habit of maintaining environmental cleanliness $(87.5 \%)$, while those who were not used to maintaining cleanliness were $21.4 \%$.

The test results using statistical software showed that the Chi-Square value was 17,927 , with $-\square=0,000$. The results revealed that there was a relationship between Habits and Garbage Disposal Behavior at a $1 \%$ significance level $(-\square<\alpha=1 \%)$. The Pearson correlation displayed 0.638 , meaning the variables of habit and garbage disposal behavior had a strong relationship.

So far, supervisions or sanctios targeting people disposing of garbage in Nizam Zachman Oceanique Fishing Port and other public areas, do not exist yet. . The Maritime Port Codes, the Marpol Regulations, and the Directive 2000/59 / EC of the European Parliament and the Council of 27 November 2000 on port reception facilities for ship-generated waste and cargo residues, oblige state members to have fixed or mobile installations. The directive is part of the community's environmental policy in line with the conventions of the International Maritime Organization. It aims to ensure the protection of the marine environment against pollution-related to maritime transport. The regulations apply to all seaports regardless of their activities (pleasure, fishing, trade) and status. Its main purposes are: to allow all users in all ports to have adequate facilities to receive operational waste and cargo residues from their vessels; - to impose on commercial vessels and certain large recreational vessels an obligation to inform the port in advance of their needs for reception facilities; - Organize and plan the reception of waste and cargo residues; Make it compulsory for ships to use the waste and residue reception facilities at their disposal, subject to a fine of up to 40,000 euros; - Finally, put in place an incentive financing mechanism based on the polluter pays principle.

Thus, there must be supervision and application of sanctions for users of the Nizam Zachman fishing port disposing of the garbage in the trash to create an ecofishing port. 


\section{CONCLUSION}

The ratio of the number of workers in NZOFP and the total workforce in the Penjaringan area of North Jakarta was $82 \%$. This number suggests that labor absorption through the sample data has met the standard of at least $20 \%$. The results of the income analysis showed that $50 \%$ of the respondents had income above Rp. 3,100,000 (above the Minimum Wage of Workers in DKI Jakarta). The analysis of respondents 'perceptions of the existence of NZOFP showed that, in general, respondents' perceptions of the existence of NZOFP were in Medium (25\%), Good (54\%), and Very Good (19\%). The analysis of respondents' behavior in disposing of garbage showed that knowledge and habit variables were factors influencing behavior, while the educational level did not affect.

\section{ACKNOWLEDGEMENTS}

The research was conducted with the support of the Indonesian Ministry of Research and Higher Education through the Doctoral Research Program (2017). Acknowledgments were also submitted to managers and management staff of Nizam Zachman Ocean Fishing Port for their positive support of this research.

\section{REFERENCES}

Badan Pusat Statistik Jakarta Utara. (2016). Data Kependudukan Kecamatan Penjaringan Tahun 2016. Jakarta: BPS Kota Jakarta Utara.

Beaulieu, D and Kuibo, B. 2001. Guide de Gestion des déchets Portuaires. Association Echo-Mer - Case 65 quai Louis Prunier 17000 La RochelleFrance. $51 \mathrm{p}$
Gubernur DKI Jakarta. (2015). Peraturan Gubernur DKI Jakarta tentang Upah Minimum Propinsi tahun 2016 (PERGUB Nomor 230 tahun 2015). Jakarta. Diakses dari https://jakarta.bpk.go.id/wpcontent/uploads/2015/11/PERGUB_N O_230_TAHUN_2015.pdf

Hakim, L.N. (2013). Pengelolaan Kualitas Lingkungan Perairan Pelabuhan Perikanan Samudera Nizam Zachman Jakarta. (theses). Depok: Universitas Indonesia. $95 \mathrm{hlm}$.

Hasibuan, M.A.S. (2013). Valuasi Ekonomi Kegiatan Pertambangan Emas Dan Persepsi Masyarakat Terhadap Dampak Sosial di Kecamatan Huta Bargot Sumatera Utara (theses). Bogor; Pascasarjana. Institut Pertanian Bogor. $51 \mathrm{hlm}$.

Kementerian Kelautan dan Perikanan. (2013). Peraturan Menteri Kelautan dan Perikanan tentang Kesyahbandaran di Pelabuhan Perikanan (PERMEN KP Nomor 3 Tahun 2013). Jakarta: KKP. Diakses dari https://peraturan.bkpm.go.id/jdih/userf iles/batang 13\%20PERMENKP\%202013.pdf

Kuncoro, M. (2013). Metode Riset untuk Bisnis dan Ekonomi (edisi 4). Jakarta: Erlangga.

Manalu, B.E., Latifa S., Patana. (2012). Persepsi Manyarakat terhadap Pengembangan Ekowisata di Desa Huta Ginjang, Kecamatan Sianjur Mula-Mula, Kabupaten Samosir, Provinsi Sumatera Utara. Jurnal Penelitian. 03. pp 5-11. Diakses dari https://jurnal.usu.ac.id/index.php/PFSJ /article/view/2047/1103

Notoatmodjo, S. 2003. Pendidikan dan Perilaku Kesehatan. Jakarta: Rineksa Cipta. 
Presiden Republik Indonesia. (2003). Undang-Undang Republik Indonesia tentang Ketenagakerjaan (UU RI Nomor 13 tahun 2003). Jakarta: Presiden Republik Indonesia. Diakses dari https://www.ilo.org/dyn/natlex/docs/E LECTRONIC/64764/ 71554 /F1102622842/IDN64764.pdf

Risnandar. (2013). Pengelolaan Lingkungan di Pelabuhan Perikanan Studi Kasus di Pelabuhan Perikanan Nusantara Palabuhanratu. (theses). Bogor: Institut Pertanian Bogor.

Santoso, S. (2015). Menguasai Statistika Multivariat. Konsep dasar dan Aplikasi dengan SPSS. Jakarta: PT Gramedia Elex Computindo.

Siahaan, E.I. (2012). Pengembangan Pelabuhan Berwawasan Lingkungan (Ecoport) Dalam Rangka Pengelolaan Pesisir Terpadu (Studi Kasus Pelabuhan Tanjung Priok). (doctoral dissertation). Bogor: Institut Pertanian Bogor.

Sugiyono. (2005). Statistika untuk Penelitian (edisi 10). Bandung: Penerbit Alfabeta.

Sugiono. (2012). Metode Penelitian Kuantitatif - Kualitatif dan R\&D. Bandung: Penerbit Alfabeta.

Widyaningrum, R. (2014). Persepsi Masyarakat tentang Keberadaan Pelabuhan Petikemas di Kelurahan Bukuan Kota Samarinda. e Journal Ilmu Administrasi Negara. 3 (2): 690701. Diakses dari https://ejournal.an.fisipunmul.ac.id/site $/$ ? $=948$

Zulfa, N., Effendy, H., Riani, E. (2016). Preliminary Rapid Fishing Port Water Quality Assessment with Pollution Index. Advances in Environmental Sciences-International Journal of the Bioflux Society. 8 (1): 96-106. 